\title{
The Effect of Efficient Market Hypothesis, Gambler's Fallacy, Familiarity Effect, Risk Perception, and Economic Factors on Investment Decisions (Studies on Capital Market Investors in Medan City)
}

\author{
Sucitra Dewi ${ }^{1)^{*}}$, Erlina $^{2)}$, Endang Sulistya Rini ${ }^{3)}$ \\ 1), 2),3) Departement of Accounting, Faculty of Economics and Business, Universitas Sumatera Utara, Medan, Indonesia
}

\begin{abstract}
This study aims to examine the effect of the efficient market hypothesis, gambler's fallacy, familiarity effect, risk perception, and economic factors on investment decisions. This research is quantitative research with a descriptive approach. The population in this study were all capital market investors in Medan City. Determination of the research sample carries out by using judgment sampling technique and Malhotra theory so that 270 samples obtain. Data analysis using multiple linear regression analysis. The results of the multiple linear regression analysis showed that the efficient market hypothesis, gambler's fallacy, familiarity effect, risk perception, and economic factors partially had a positive and significant impact on investment decision making. Other results, the efficient market hypothesis, gambler's fallacy, familiarity effect, risk perception, and economic factors simultaneously have a positive and significant impact on investment decision making.
\end{abstract}

Keywords:- Efficient Market Hypothesis, Gambler's Fallacy, Familiarity Effect, Risk Perception, Economic Factors, Investment Decisions

\section{INTRODUCTION}

In this rapid development era, investment becomes an activity that is familiar in society. Where someone who is at a productive age tends to want and fulfil needs through the selection of assets or products that can be stored to obtain returns in the future. This income will be used to meet future needs. Therefore, investment defines as financial preparation by sacrificing present sources of funds in the hope of generating future profits. In general, sector assets that can use as investment advice divided into two, namely the real sector and the financial sector. Investment in the real industry is investing or buying productive assets to produce a specific product through the production process. Types of investments intangible assets are houses, land and gold. Meanwhile, investment in the financial sector is an activity of buying and selling financial assets or valuable documents in the hope of making a profit. Types of investment in financial assets include savings, deposits, mutual funds, bonds, stocks, gold, property, and others.
Based on data released by PT Kustodian Sentral Efek Indonesia (KSEI), the total capital market investors in Indonesia as of December 27, 2019, reached 2.47 million investors. This number has significantly increased from 1.61 million in the full year 2018 period. According to the same data, the distribution of investors is still concentrated in Java with an investor composition of $71.75 \%$ and controlling $95.31 \%$ of Indonesia's capital market assets. Followed then by the island of Sumatra with a total of $15.36 \%$ of the total SID and having assets of $1.28 \%$. Furthermore, Kalimantan Island, which contributed $4.94 \%$ of capital market investors with a more significant amount of assets, namely $2.98 \%$ of total capital market assets. Sulawesi contributed $3.57 \%$ to the number of investors in the capital market with only $0.19 \%$ assets. The next region in Bali, NTT, NTB, Maluku and Papua which each accounted for $3.13 \%$ and $1.24 \%$ of investors with a composition of assets of $0.17 \%$ and $0.07 \%$ of total capital market assets.

Based on the availability of information, the capital market can be said to be an efficient capital market if new information from both the government of a country and the issuer or company concerned will spread widely, quickly and easily and be obtained cheaply by market players or investors, (Dwipayana and Wiksuana, 2017). Based on the rationality and ability investors in analyzing the available information for decision making, the efficiency of the capital market can be viewed in terms of the availability of information and also from the perspective of the sophistication market players in making decisions. Market efficiency seen for information calls information market efficiency, while market efficiency viewed from the sophistication of market players in making decisions based on available information is called market efficiency by decision. In this thesis, a review of the effectiveness of the capital market places more emphasis on ability in terms of market efficiency by decision (Tjandra, 2006).

Apart from observing market efficiency, investors in their decision making are influenced by a behavioural bias which can prevent investors from making rational decisions. Behavioural bias defines as a pattern of variation in decision making that occurs in certain situations. It sometimes causes changes in perceptions, inaccurate judgments, logical interpretations, or often called irrationality (Verma, 2016). Behavioural bias can 
characterize by the emergence of various behaviours, including the gambler's fallacy and the familiarity effect (Djojopranoto and Mahadwartha, 2016). According to Shefrin and Statman (1985) and Odean (1998), investors will experience gambler's fallacy in investing, such as when gambling. Gambler's fallacy arises from renewing negative experiences where investors have a logical concept that stocks that in previous periods experienced a price decrease and even stayed at the same price will have a high probability of experiencing the different event in the future (Ayton and Fischer, 2004).

According to Heath and Tversky (1991), people tend to be more willing to speculate when they feel they understand the situation. In this situation of ambiguity aversion, people tend to choose risks that know with certainty over those that are uncertain. People prefer familiar things to new things. It triggered the familiarity effect. This phenomenon shows that the investment decisions of individual investors not purely based on company fundamentals as suggested by traditional financial theory, but there may be an influence from the positive or negative attitudes they have towards certain company products and brands, (Vries et al., 2017). Another factor that influences the investment decision is risk perception. Perception is the process by which individuals regulate and interpret investor censorship impressions to give meaning to the investor's environment (Robbins and Judge, 2008: 175). Williamson and Weyman (2005) define risk perception as the result of many factors that become the basis of differences in decision making on possible losses. Investor behaviour in making decisions influenced by the subjective attitude they have towards the risk and investment income itself. Investors who have a high-risk perception ability will more often rethink their investment decisions.

Apart from behavioural bias actions carried out by an individual, economic factors also cause a person to make a decision. Economic factors are the circumstances or financial conditions of a person/institution in making investment decisions. The economic factor seen is from the company side. Examples of economic factors studied by Aregbeyen (2011) are dividend payments, company financial performance, daily activity reports, stock value predictions, and bonuses. Financial performance shows how effective and efficient an organization is in achieving its goals.

\section{LITERATURE REVIEW}

\section{A. Investment Decision-Making Theory}

In the theory of decision making, there are several supporting theories, namely Decision Usefulness Approach, Single-Person Decision Theory, The Rational Risk-Averse Investor, The Optimal Investment Decision. This singleperson theory of decision provides a reasonable basis for individuals who begin to make rational decisions under uncertainty. This theory allows us to appreciate the concept of information that makes it easier for decision-makers to sharpen their subjective beliefs about future returns on decisions. Regarding the risk-aversion model, decision theory uses a tool, namely a utility function that connects the amount of payment with the utility of the decisionmaker on that amount. Sometimes there is an assumption that the decision-maker is risk-neutral; that is, the decisionmaker will carefully analyze the risky investment with the expected payment. Risk-averse will equalize (trade-off) between the return and the expected risk of an investment. Scott (2009) states that when transaction costs ignored, the optimal decision of a risk-averse investor is to buy a combination of the market portfolio and risk-free assets that results in the best trade-off between expected return and risk. Investing in a portfolio generates less risk than investing in a single company for the same rate of return.

\section{B. Behaviour-based Financial Theory}

The behaviour-based financial theory was coined by G.C. Selden in 1912, based on classical and neoclassical economic theory, (Wijayanti, 2015). Financial behaviour (behavioural finance) is a study that aims to understand investor behaviour in making investment decisions (Puspitaningtyas, 2014).

\section{Efficient Market Hypothesis Theory}

Efficient market hypothesis theory refers to information circulating in the market that can influence investment decisions.

\section{Modern Portfolio Theory}

Modern Portfolio Theory (MPT) also called portfolio theory or portfolio management theory, is a sophisticated investment approach/strategy and is a philosophical opposite of traditional stock theory taking. Theory economists were trying to understand the market as a whole, not business analysts looking for what makes each investment opportunity unique. Investments describe statistically to consider the expected long-term rate of return and the expected short-term volatility rate.

\section{E. Relevant Dividend Theory}

This theory states that dividends are more satisfied than the "thousand" capital gains in the air. Profits are more predictable. Meanwhile, capital gains are considered likely to be obtained from speculation because stock prices can change at any time.

\section{F. Investment Decision}

Decision making is one of the underlying cognitive processes of human behaviour in which choices or actions selected from a set of alternatives based on specific criteria (Wang and Ruhe, 2007). Rational investors in decisionmaking theory mean that in decision making, the action chosen is the one that produces the highest expected utility (Puspitaningtyas, 2012). However, the concept of financial behaviour explained that investors in investing not only use estimates of the prospects of investment instruments, but psychological factors also have a significant role in determining decision making. 


\section{G. Efficient Market Hypothesis}

Capital market efficiency (Efficient Market) is a condition in which a stock price adjusts quickly with additional information, and therefore the stock price includes all available information (Relly \& Brown, 2012). From the information circulating in the market, this information can influence investment decision making.

\section{H. Gambler's Fallacy}

Gambler's fallacy is a false representation of events that occurred in the past in decision making. Gambler's fallacy is an inaccurate representation of events that happened in the past in decision making.

\section{Familiarity Effect}

In the context of the capital market, the familiarity effect often described as the tendency of investors to buy individual shares. It then will form a portfolio that is not diversified because of the selection based on geographical proximity, professional closeness and cultural patriotism. Especially if an investor knows the risk and return of a specific form of investment, usually, the investor is more confident and follows this type of investment (Lestari and Iramani, 2013).

\section{J. Risk Perception}

Risk Perception is a process where someone interprets information about the risk that obtained. Williamson and Weyman (2005) define risk perception as the result of many factors that form the basis of differences in decision making regarding possible losses. Perceptual problems and tendencies then impact an individual's readiness to take risks. Such availability may depend either on the uncertainty the results due to imperfect knowledge or the scale of potential losses or gains.

\section{K. Economic factors}

Economic factors are things that affect financial or business activities in meeting the daily needs of life to achieve prosperity. Economic considerations associated with making investment decisions that investors will first see the economic condition of a company that will be a place to invest. Indicators that can explain economic factors in investment decision making are (Aregbeyen, 2011): dividends paid annually, the latest financial performance of the company, IHSG daily activity report on profit/loss, predictions of a reputation for future stock price increases, and bonuses.

\section{Framework}

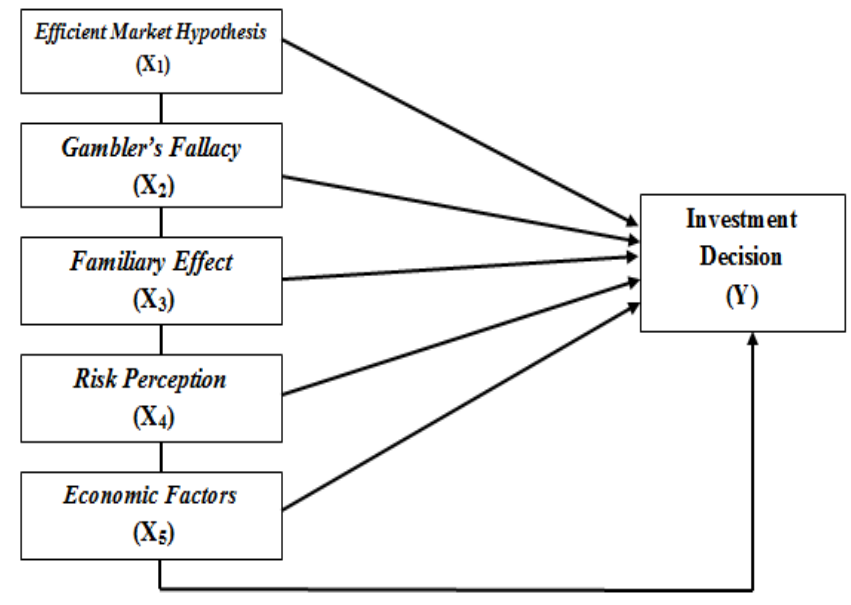

Fig 1

M. Hypothesis

H1: Efficient market hypothesis affects investment decisions.

H2: Gambler's fallacy affects investment decisions.

H3: Familiarity effect influences investment decisions.

H4: Risk Perception affects investment decisions.

$\mathrm{H} 5$ : Economic factors influence investment decisions.

H6: Efficient market hypothesis, gambler's fallacy, familiarity effect, risk perception and economic factors influence investment decisions.

\section{RESEARCH METHODOLOGY}

\section{A. Research Approach}

This type of research is associative explanatory research, namely research that aims to determine the relationship between two or more variables (Kurniawan, 2012: 21).

\section{B. Data Analysis Methods}

The data analysis method used in this study is a statistical analysis method using Amos 25 software-data analysis performed by testing standard assumptions and testing hypotheses.

\section{RESULT}

\section{A. Analysis of Structural Equation Modelling}

Structural equation 287odeling analysis used to determine the fundamental relationship between the variables studied. The essential link between variables tested for conformity with the goodness of fit index. The results of the Structural Equation Modeling (SEM) analysis in this study can see in the following figure: 


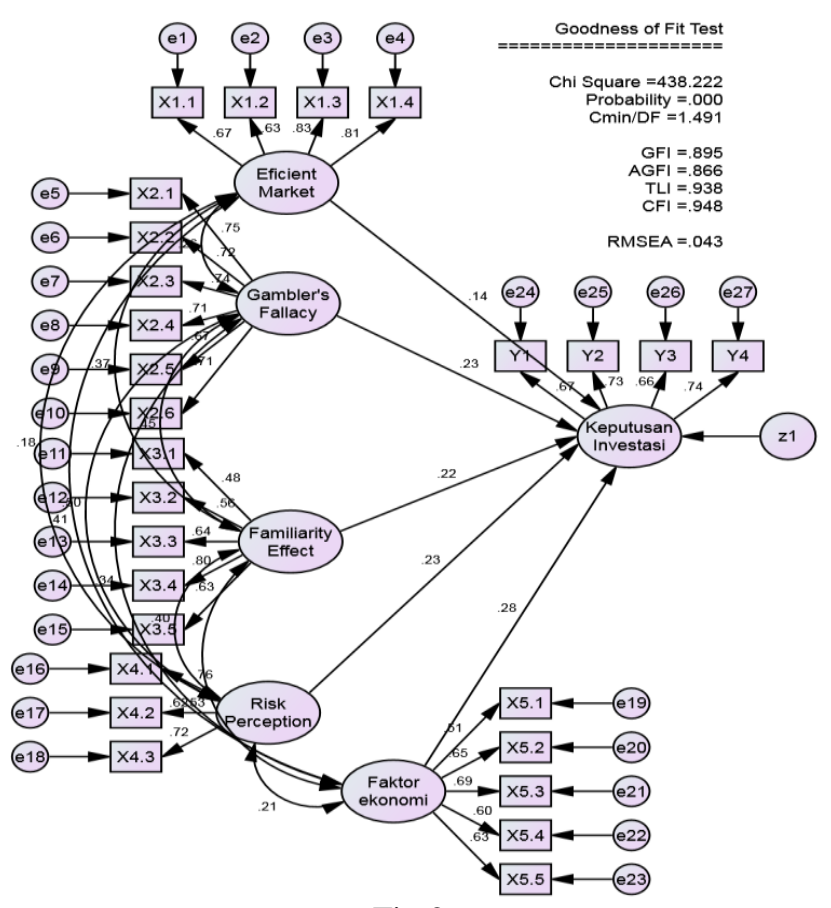

Fig 2

The results of the model feasibility test (Goodness Fit Model) from the image above are as follows: of Fit)

Feasibility Testing Index Measurement (Goodness

\begin{tabular}{|c|c|c|c|}
\hline $\begin{array}{c}\text { Goodness } \\
\text { of fit }\end{array}$ & Cut - off Value & $\begin{array}{c}\text { Model } \\
\text { Results }\end{array}$ & Information \\
\hline $\begin{array}{c}\mathrm{X}^{2}-\text { Chi- } \\
\text { Square }\end{array}$ & $\begin{array}{c}\text { Expected to be } \\
\text { of small value } \\
\text { With DF=294 } \\
\text { the table value } \\
334.98\end{array}$ & 438.222 & Not good \\
\hline Probability & $\geq 0,05$ & 0,000 & Not good \\
\hline Cmin/DF & $\leq 2$ & 1,491 & Good \\
\hline GFI & $\geq 0,90$ & 0,895 & Marginal \\
\hline RMSEA & $\leq 0,079$ & 0,043 & Good \\
\hline AGFI & $\geq 0,90$ & 0,866 & Marginal \\
\hline TLI & $\geq 0,90$ & 0,938 & Good \\
\hline CFI & $>0,90$ & 0,948 & Good \\
\hline
\end{tabular}

Table 1

Overal this model shows a good model. Regarding the opinion expressed by Hair et al. (2011), the path model proposed in this study has met the assumption of Goodness of Fit (a good fit model).

\section{B. Direct Influence}

Hypothesis testing conducted to determine the effect or absence of the independent variable on the dependent variable. The hypothesis is accepted if the prob $(\mathrm{P})$ value $<0.05$. The partial results of hypothesis testing can see in the table below:

\section{Standardized Regression Weight Structural Equation Modelling}

\begin{tabular}{|c|c|c|c|c|}
\hline & $\begin{array}{c}\text { Standard } \\
\text { Estimate }\end{array}$ & C.R. & $\mathrm{P}$ & $\mathrm{P}$ \\
\hline $\mathrm{Y} \leftarrow-\mathrm{X} 1$ & 0.141 & 2.142 & 0.032 & $\begin{array}{c}\text { Significant }(\mathrm{H} 1 \\
\text { accepted) }\end{array}$ \\
\hline $\mathrm{Y} \leftarrow-\mathrm{X} 2$ & 0.230 & 3.083 & 0.002 & $\begin{array}{c}\text { Significant }(\mathrm{H} 2 \\
\text { accepted) }\end{array}$ \\
\hline $\mathrm{Y} \leftarrow-\mathrm{X} 3$ & 0.222 & 2.683 & 0.007 & $\begin{array}{c}\text { Significant }(\mathrm{H} 3 \\
\text { accepted) }\end{array}$ \\
\hline $\mathrm{Y} \leftarrow-\mathrm{X} 4$ & 0.233 & 3.054 & 0.002 & $\begin{array}{c}\text { Significant }(\mathrm{H} 4 \\
\text { accepted) }\end{array}$ \\
\hline $\mathrm{Y} \leftarrow-\mathrm{X} 5$ & 0.280 & 3.366 & 0.000 & $\begin{array}{c}\text { Significant }(\mathrm{H} 5 \\
\text { accepted) }\end{array}$ \\
\hline
\end{tabular}

Table 2

Based on the results of the table above, it obtained the results of hypothesis testing that the efficient market hypothesis, gambler's fallacy, familiarity effect, risk perception, and economic factors have a partial effect on investment decisions.

\section{Simultaneous Influence}

The simultaneous influence hypothesis test carried out to find out whether or not the independent variable simultaneously influences the dependent variable. The hypothesis is accepted if the prob $(\mathrm{P})$ value $<0.005$. The following table shows the results of the simultaneous influence:

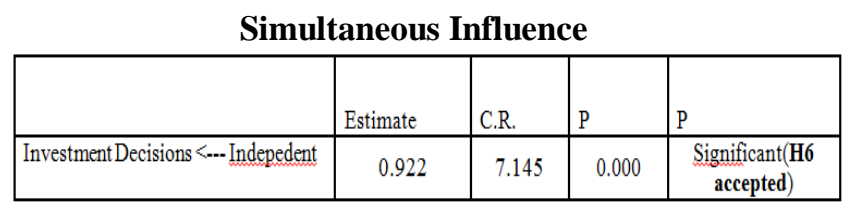

Table 3

Based on the table above, the results of the hypothesis test from AMOS data processing show a probability of $0.000<0.005$, which means that H6, namely the efficient market hypothesis, gambler's fallacy, familiarity effect, risk perception, and economic factors simultaneously influence investment decisions.

\section{CONCLUSION AND RECOMMENDATION}

\section{A. Conclusions}

Based on the results of research and discussion in the previous chapter, several findings are Efficient market hypothesis, gambler's fallacy, familiarity effect, risk perception, and economic factors partially and simultaneous have a positive and significant impact on investment decisions. 


\section{B. Suggestions}

Based on the results of the analysis, discussion and conclusions, the implications of the research that have carried out stated in the form of suggestions provided through research results to get better results, namely: (1) Investors advised considering the results of this study as a reference intake investment decisions and illustrated that in decision making there are rational and irrational factors that influence, (3) For further researchers, it can clarify the sample criteria and take samples from mature investors. Mature in question is an investor who has more than three years experience, (4) This research expected to be a useful reference material for conducting further research related to the effect of efficient market hypothesis, gambler's fallacy, familiarity effects, risk perception and economic factors have a positive influence and significant to investment decisions (study on the capital market in Medan City).

\section{REFERENCES}

[1]. Adhi, Yunan Kurniawan. (2012). Sistem Pendukung Pengambilan Keputusan Penjurusan Siswa SMA dengan Metode Simple Multi Attribute Rating Technique (SMART) dan Artificial Neural Network (ANN). Skripsi. Telkom University Bandung..

[2]. Amin, Amjad, Sehrish Shoukat dan Zahoor Khan. (2009). Gambler's Fallacy and Behavioral Finance in the Financial Markets (A Case Study of Lahore Stock Exchange). Abasyn University Journal of Social Sciences, 3(2): 67-73.

[3]. Aregbeyen, Oma. (2011). Factors Influencing Investors Decisions in Shares of Quoted Companies in Nigeria. Article Review.

[4]. Ayton, Peter, dan Ilan Fischer. (2004). The Hot Hand Fallacy and The Gambler's Fallacy: Two Faces of Subjective Randomness?. Memory and Kognisi, 32:1369-1378.

[5]. Bahri, M. Saiful. (2018). Pengaruh risk tolerance, risk perception, dan kecerdasan spiritual terhadap keputusan investasi saham di Surabaya. Artikel Ilmiah. STIE Perbanas.

[6]. Bashir, Taqqadus. (2013). Impact of Behavioral Biases on Investors Decision Making: Male Vs Female. IOSR Journal of Business and Management, 10(3): 60-68.

[7]. Cao, H. Henry, Bing Han, David Hirshleifer dan Harold H. Zhan. (2011). Fear of the Unknown: Familiarity and Economic Decisions. Review of Finance, 15: 173-206.

[8]. Chen, Gongmeng, Kenneth A, Kim, John R. Nofsinger dan Oliver M. Rui. (2007). Trading Performance, Disposition Effect, Overconvidance, Representativeness Bias, and Experience of Emerging Market Investors. Journal Behavioural Decision Making, 20(4): 425-451.

[9]. Croson, Rachel, dan James Sundali. (2005). The Gambler's Fallacy and the Hot Hand: Empirical Data from Casinos. Journal of Risk and Uncertainty, 30 (3):195-209.
[10]. Danepo, Muhammad. (2018). Pengaruh Bias Perilaku Investor terhadap Keputusan investasi di Pasar Saham (Studi pada Bursa Efek Indonesia). Tesis. Universitas Lampung.

[11]. Djojopranoto, Riana Rahmawati, dan Putu Anom Mahadwartha. (2016). Pengujian Bias Perilaku: Gambler's Fallacy, Halo Effect, dan Familiarity Effect di Pasar Modal Indonesia. Jurnal Akuntansi dan Keuangan Indonesia, 13(2): 142-159.

[12]. Dittrich, Dennis, Werner Güth dan Boris Maciejovsky. (2001). Overconfidence in Investment Decisions-An Experimental Approach. CESifo Working Paper Series No. 626.

[13]. Dwipayana, I Gusti Ngurah Agung Putra, dan I Gusti Bagus Wiksuana. (2017). Pengujian Efisiensi Pasar di Bursa Efek Indonesia. E-Jurnal Manajemen Unud, 6(4): 2105-2132.

[14]. Dwi Siswoyo, dkk. 2013. Ilmu Pendidikan. Yogyakarta: UNY Press.

[15]. E.Fama. (1970). Efficient capital markets: a review of theory and empirical work.Journal Finance, 383-417.

[16]. Erlina, (2011). Metodologi Penelitian, USU Press, Medan.

[17]. Fakhry, Bachar. (2016). A Literature Review of the Efficient Market Hypothesis. Turkish Economic Review, 3(3): 431-442.

[18]. Feng, Lei, dan Mark S. Seasholes. (2005). Do Investor Sophistication, and Trading Experience Eliminate Behavioral Biases in Financial Markets? Review of Finance, 9(3): 305-351.

[19]. Ferdinand, Augusty. (2000). Structural Equation Modelling dalam Penelitian Manajemen. Badan Penerbit UNDIP. Semarang.

[20]. Ghozali, Imam. (2013). Aplikasi Analisis Multivariate dengan Program SPSS Edisi 3. Semarang: Badan Penerbit Universitas Diponegoro.

[21]. Ghozali, Imam. (2014). Structural Equation Modelling, Metode Alternatif dengan Partial Least Square (PLS), Badan Penerbit UNDIP, Semarang.

[22]. Gunathilaka, Chandana. (2013). Factors Influencing Stock Selection Decision the Case of retail Investors in Colombo Stock Exchange. Conference Paper. The University of Sri Jayewardenepura.

[23]. Hamid, Kashif, Muhammad Tahir Suleman, Syed Zulfiqar Ali Shah dan Rana Shahid Imdad Akash. (2010). Testing the Weak form of Efficient Market Hypothesis: Empirical Evidence from Asia-Pacific Markets. International Research Journal of Finance and Economics, 58: 121-133.

[24]. Hair, J.F. (2006). Multivariate Data Analysis. Edisi 5. Jakarta: Gramedia Pustaka Utama.

[25]. Heath, Chip, dan Amos Tversky. (1991). Preference and Belief: Ambiguity and Competence in Choice under Uncertainty. Journal of Risk and Uncertainty, 4(1): 5-28.

[26]. Herschberg, Miguel. (2012). Limits to Arbitrage: An introduction to Behavioral Finance and a Literature Review. Palermo Business Review, 7: 7-21.

[27]. Julianita, Winda dan Sarjono, Haryadi, 2015. Structural Ewuation Modelling, Salemba Empat, Jakarta. 
[28]. Kartini dan Nuris Firmansyah Nugraha. (2015). Pengaruh Illusions of Control, Overconfidence dan Emotion terhadap Pengambilan Keputusan investasi pada Investor di Yogyakarta. Jurnal Inovasi dan Kewirausahaan, 4(2): 115-123.

[29]. Khajar, Ibnu. (2008). Pengujian Efisiensi dan Peningkatan Efisiensi Bentuk Lemah Bursa Efek Indonesia Pada Saat dan Sesudah Krisis Moneter pada Saham-Saham LQ-45. Jurnal Manajemen Teori dan Terapan.

[30]. Kudryavtsev, Andrey. (2018). The Gambler's Fallacy in the Stock Markets: Investors' Beliefs in Stock Price Reversals. International Journal of Economic Theory and Application, 5(1): 1-6.

[31]. Lestari, Murti. (2005). Pengaruh Variabel Makro terhadap Return Saham di Bursa Efek Jakarta: Pendekatan Beberapa Model. Simposium Nasional Akuntansi 8 Solo: 504-515.

[32]. Lestari, Wiwik, dan Rr. Iramani. (2013). Persepsi Risiko dan Kecenderungan Risiko Investor Individu. Jurnal Keuangan dan Perbankan, 17(1): 78-88.

[33]. Maharani, Satia Nur. (2014). Rekonsiliasi Perseteruan antara Efficient Market Hypothesis dan Behavioral Finance melalui Perspektif Neuroeconomics. Jurnal Akuntansi Multiparadigma.

[34]. Maharani, Satia Nur. (2016). How Neuroeconomics in Explaining the Investors Behavior. International Journal of Business, Economics and Law.

[35]. Malhotra, N. K. (2010). Marketing Research An Applied Orientation. United States of America: Prentice-Hall.

[36]. Malkiel, Burton G. (2003). The Efficient Market Hypothesis and Its Critics. The Journal of Economic Perspectives, 17(1): 59-82.

[37]. Musthofa, AH. Rizki Zainal. (2018). Pengaruh Risk Perception, Representativeness, dan Familiarity Effect terhadap Pengambilan Keputusan investasi Saham di Surabaya. Artikel Ilmiah. STIE Perbanas.

[38]. Natapura, Cecilia. (2009). Analisis Perilaku Investor Institusional dengan Pendekatan Analytical Hierarchy Process (AHP). Jurnal Ilmu Administrasi dan Organisasi, 16(3): 180-187.

[39]. Oliveira, Arnaldo. (2007). A Discussion of Rational and Psychological Decision-Making Theories and Models: The Search for a Cultural-Ethical DecisionMaking Model. Electronic Journal of Business Ethics and Organization Studies, 12(2): 12-17.

[40]. Parmitasari, Rika Dwi Ayu. (2017). Gender dan Kepuasan Keuangan Investor Pasar Modal di Sulawesi Selatan. Patria Artha Manajemen Journal, 1(2): 247-266.

[41]. Parmitasari, Rika Dwi Ayu, Djabir Hamsah, Syamsul Alam dan Abd. Rakhman Laba. (2018). Analysis of Ethics and Investor Behavior and Its Impact on Financial Satisfaction of Capital Market Investors. Scientific Research Journal, 6(1): 51-69.

[42]. Prawirasasra, Kannya Purnamahatty. (2016). Behavioural Finance in Investment Decision- Making Process. Proceedings of 66th The IIER International Conference, Seoul, South Korea, 36-38.
[43]. Puspitaningtyas, Zarah. (2012). Relevansi Nilai Informasi Akuntansi dan Manfaatnya Bagi Investor. Ekuitas: Jurnal Ekonomi dan Keuangan, 16(2): 164183.

[44]. Puspitaningtyas, Zarah. (2014). Perilaku Investor dalam Pengambilan Keputusan investasi di Pasar Modal. Forum Ilmiah Nasional, 54.

[45]. Qawi, Raluca Bighui. (2002). Behavioural Finance: Is Investor Psyche Driving Market Performance? IUP Journal of Behavioral Finance, 7(4) (2010): 7-19. Rabin, Matthew. Inference by Believers in the Law of Small Numbers. Q.J. Economic, 117(3): 775-816.

[46]. Rakesh. (2013). Gambler's Fallacy and Behavioral Finance in the Financial Markets: A Case Study of Bombay Stock Exchange. International Journal of Business and Management Invention, 2(2): 1-7.

[47]. Rakhmatulloh, Afriani Dwi, dan Nadia Asandimitra. (2019). Pengaruh Overconfidence, Accounting Information, dan Behavioural Motivation terhadap keputusan investasi di Kota Surabaya. Jurnal Ilmu Manajemen Volume 7 Nomor 3. Universitas Negeri Surabaya.

[48]. Ritter, Jay R. (2003). Behavioural Finance. PacificBasin Finance Journal, 11(4): 429-437.

[49]. Santoso, Singgih. (2015). Structural Equation Modelling (SEM), Konsep dan Aplikasi dengan AMOS. PT. Elex Media Komputindo Kompas Gramedia, Jakarta.

[50]. Sekaran, Uma. (2006). Metodologi Penelitian Untuk Bisnis Buku 1, Terjemahan, Edisi 4. Jakarta: Salemba Empat.

[51]. Silvia, Rizqa Merina. (2013). Pengaruh faktor eksternal terhadap risk reception dan risk atitude dalam pengambilan keputusan investasi di pasar modal. Artikel Ilmiah. Sekolah Tinggi Ilmu Ekonomi Perbanas.

[52]. Sindhu, K., \& Kumar, R. (2014). Influence of Risk Perception of Investors on Investment Decisions: An Empirical Analysis. Journal of Finance and Bank Management, 2(2), 15-25.

[53]. Sitinjak, Elizabeth Lucky Maretha. (2013). Perilaku Investor Individu dalam Pembuatan Keputusan investasi Saham: Efek Disposisi dan Informasi Akuntansi. Jurnal Organisasi dan Manajemen.

[54]. Septyanto, Dihin. (2013). Faktor-Faktor yang Mempengaruhi Investor Individu dalam Pengambilan Keputusan investasi Sekuritas di Bursa Efek Indonesia (BEI). Jurnal Ekonomi, 4(2): 90-101.

[55]. Sewell, Martin. (2012). The Efficient Market Hypothesis: Empirical Evidence. International Journal of Statistics and Probability, 1(2): 164-178.

[56]. Shahzad, Syed Jawad Hussain, Paeman Ali, Fawad Saleem, Sajid Ali dan Sehrish Akram. (2013). Stock Market Efficiency: Behavioral of Traditional Paradigm? Evidence from Karachi Stock Exchange and Investor Community of Pakistan. Interdisciplinary Journal of Contemporary Research in Business, 4(10): 605-619. 
[57]. Shefrin, Hersh, dan Meir Statman. (1985). The Disposition to Sell Winners Too Early and Ride Losers Too Long: Theory and Evidence. The Journal of Finance, 40(3): 777-790.

[58]. Stock, Thomas, Jurgen Huber, Michael Kirchler dan Florian Lindner. (2015). Hot Hand and Gambler's Fallacy in Terms: Evidence from Investment Experiments. Journal of Economic Behaviour and Organization, 117: 327-339.

[59]. Sudirman, I Made Surya Negara, dan Bambang Hadi Santoso Dwijosumarno. (2013). Investor Behavior in the Investment Decision Making: Are Expected Utility Theory, Prospect Theory, and Belief System Theory Have the Ability to Explain?. Forum Ilmial Nasional, 54.

[60]. Sugiyono. (2013). Statistika untuk Penelitian. Bandung: Alfabeta.

[61]. Sugiyono. (2017). Metode Penelitian Bisnis Pendekatan Kuantitatif, Kualitatif, Kombinasi, dan R\&D. Bandung: Alfabeta.

[62]. Sun, Yanlong, dan Hongbin Wang. (2010). Gambler's fallacy, Hot Hand Belief, and the Time of Patterns. Judgment and Decision Making, 5(2): 124-132.

[63]. Tjandra, Ronowati. (2006). Pengujian Efisiensi Pasar Setengah Kuat Secara Informasi terhadap Pengumuman Inisiasi Dividen (Studi Empiris pada Perusahaan- Perusahaan yang Terdaftar di Bursa Efek Jakarta Periode Tahun 2000- 2003). Jurnal Akuntansi dan Investasi, 7(2): 175-194. [49]. Sugiyono.

(2017). Metode Penelitian Bisnis Pendekatan Kuantitatif, Kualitatif, Kombinasi, dan R\&D. Bandung: Alfabeta.

[64]. Tversky, Amos, dan Daniel Kahneman. (1981). The Framing of Decisions and the Psychology of Choice. Science, 211: 453-458.

[65]. Verma, Neha. (2016). Impact of Behavioral Biases in Investment Decision and Strategies. Journal of Management Research and Analysis, 3(1): 28-30.

[66]. Vries, Annalien De., Pierre D. Erasmus dan Charlene Gerber. (2017). The Familiar Versus the Unfamiliar: Familiarity Bias Amongst Individual Investors. Acta Commercii - Independent Research Journal in the Management Sciences, 17(1): 1-10.

[67]. Wang, Yingxu, dan Guenther Ruhe. (2007). The Cognitive Process of Decision Making. International Journal of Cognitive Informatics and Natural Intelligence, 1(2): 73-85.

[68]. Weber, Elke U., dan Christopher Hsee. (1998). Crosscultural Differences in Risk Perception, but Crosscultural Similarities in Attitudes Towards Perceived Risk. Management Science, 44(9): 1205-1217a.

[69]. Weber, Elke U., dan Christopher Hsee. (1998). Crosscultural Differences in Risk Perception, but Crosscultural Similarities in Attitudes Towards Perceived Risk. Management Science, 44(9): 1205-1217.

[70]. Wendy. (2010). Apakah Investor Saham Menderita Myopic Loss Aversion? Eksperimen Laboratory. Journal Bisnis dan Ekonomi, 17(85): 85-96.

[71]. Widyastuti, Indriyana. (2010). Efisiensi Pasar Modal sebagai Alat Analisa Sekuritas. PROBANK, 18(8): 115. 107.
[72]. Wijayanthi, Isnawatie Mawadha. (2015). Studi Deskriptif: Perilaku Investor Saham di Surabaya Berdasarkan Aspek Psikologi, Demografi dan Rasionalitas. Jurnal Ilmiah Mahasiswa Universitas Surabaya, 4(2): 1-17.

[73]. Wulandari, Dewi Ayu dan Rr. Iramani. (2014). Studi Experienced Regret, Risk Tolerance, Overconfidance dan Risk Perception pada Pengambilan Keputusan investasi Dosen Ekonomi. Journal of Business and Banking, 4(1).

[74]. Xu, Juemin dan Nigel Harvey. (2014). Carrying on Winning: The Gambler's Fallacy Creates Hot Hand Effect in Online Gambling. Cognition. 134: 173-180.

[75]. Yang, Zhen Hua., Jian Guo Liu., Chang Rui Yu dan Jing Ti Han. (2017). Quantifying the Effect of Investors Attention on the Stock Market. PLOS ONE, 12(5).

[76]. Yusraa, Sidrah. (2018). Pengaruh Efficient Market Hypothesis, Gambler's Fallacy, dan Familiarity Effect terhadap Investment Decision Making dengan Perspektif Neuroeconimics sebagai Variabel Moderasi (Studi pada Investor Pasar Modal di Kota Makassar). Skripsi. Universitas Islam Negeri Alauddin Makassar. 